\title{
DETECTION OF BRUCELLA IN MARKETABLE MILK SOLD IN ALEXANDERIA CITY
}

\author{
AMANY F. ZAYED ${ }^{1}$; KHALID A. ABOU GAZIA ${ }^{2}$ and MAGDY, THABET GERGES ${ }^{1}$ \\ ${ }^{1}$ Animal Health Research Institute, Food Control Department \\ ${ }^{2}$ Animal Reproduction Research Institute, Brucella Unit.
}

Received: 23 March 2017; Accepted: 30 April 2017

\begin{abstract}
The main object of this study is to detect the Brucella spp. in the marketable milk sold in Alexanderia city by using different methods such as MRT (milk ring test), ELISA, direct culture and PCR. A total of 170 milk samples were purchased as 70 cow's milk samples and 100 buffalo's milk samples. The obtained results indicated that the incidence of Brucella antibodies in milk samples were estimated by MRT in 16 samples (7 cow's milk and 9 buffalo's milk) out of the 170 milk samples ; and by ELISA in 35 samples (19 cow's milk and 16 buffalo's milk) out of the 170 milk samples. Moreover, Brucella spp. were detected in $4.3 \%$ of the cow's milk samples and $5 \%$ of the buffalo's milk samples by direct culture. Also the incidence of Brucella spp. gene were detected in 14 samples $(8.2 \%)$ out of the 170 milk samples as $6(8.6 \%)$ for cow's milk and $8(8 \%)$ for buffalo's milk samples by using PCR. In conclusion, PCR proved to be more suitable tools for Brucella detection than the culture techniques. A combination between molecular techniques and conventional techniques found to be a good reliable policy for controlling the disease. Achieved results set a warning for public health hazard due to habit of drinking of fresh raw milk.
\end{abstract}

Key words: Brucella spp., marketable milk, MRT, ELISA, PCR.

\section{INTRODUCTION}

Brucellosis, also known as"undulant fever", "Mediterranean fever" or "Malta fever" is a highly contagious bacterial zoonotic disease that affect millions of people worldwide and a wide variety of farm animals (Mohsen, 2000; Bricker, 2002) and still remains a significant public health and economic problem in many developing countries (Hassan and Samaha, 2008). Six countries in the Middle East, report an annual total of more than 90000 cases of human brucellosis and the patient undergo long time of antibiotic treatment (FAO / WHO, 1995); The dairy animals, cattle, sheep, goat and camels are included within the reservoirs of the agent resulting in a decrease in reproductive efficiency and abortion (Adams and Moss, 1995), Moreover, it is a major reason for culling of animals due to the strategy of eradication program (Hopper et al., 1989). Man is often infected bydirect or indirect contact with the contaminated fetal membranes and infected animals or their products (Young, 1983; Wallach et al., 1994) via consumption of contaminated foods, so it is also considered as food borne disease (Young, 1983).

Corresponding author: Dr. AMANY F. ZAYED

E-mail address: amany.zayed4@yahoo.com

Present address: Animal Health Research Institute, Food Control Department
In the dairy animals, Brucella centralize in the supramammary lymph nodes which continue to excrete them in the milk (Cordes and Carter, 1979; Refai, 2003).

The genus of Brucella comprises of Gram-negative, non-motile and facultative intracellular pathogens and six species are recognized within the genus: Brucella melitensis, B.abortus, B. ovis, B. canis, B. suis and B. neotomae (Moreno et al., 2002). All six Brucella spp. are considered to be potentially pathogenic to humans (Corbel and Brinley-Morgan, 1984). Brucella melitensis is the most virulent strain for humans. It is considered a level B biological weapon (Hoover et al., 2004). Brucella melitens biovar-3 considered as prevalent biovar in Egypt and reported an incidence of $61.0 \%$ in cattle and $24.0 \%$ in buffaloes (Ibrahim et $a l ., 2012)$. It is naturally infected raw milk and survived for 5 days at $4{ }^{\circ} \mathrm{C}$ and for 9 days at $-20{ }^{\circ} \mathrm{C}$ (Hassan and Samaha, 2008).

The methods for the diagnosis of brucellosis firstly by serological tests via detection of antibodies specific for Brucella infection (Refai, 2003). Culture methods are well established for brucellosis but highly pathogenic for laboratory workers, difficult and lengthy processes that requires experienced technicians, finally, culture takes long time to growth (Kazemi et al., 2008). Serological methods are not conclusive, because of the absence of the detectable level of antibodies by the infected animals. However, 
milk ring test (MRT) is probably the most widely used test for screening and monitoring of brucellosis in dairy cattle (Alton et al., 1988). PCR as amolecular techniquesh as the potential to meet the need for better diagnostic tools for several infectious diseases which caused by fastidious or slow growing bacteria (Romero et al., 1995; Bricker, 2002).

\section{MATERIALS AND METHODS}

\section{1-Collection of samples:}

A total of 170 milk samples (70 cow's milk and 100 buffalo's milk) were collected from local markets in Alexanderia city. The samples were obtained as they sold and well mixed, then put in sterile poly ethylene bags and transported to the laboratory in an ice box, and freezed until analysis at Animal Reproduction Research Institute (Brucella Unit).

\section{2-Milk Ring Test (MRT):}

The test was performed in sterile was serman's tubes. The milk samples were thoroughly shaken and $1 \mathrm{ml}$ of the milk was transferred into a tube and a drop (30 $\mu 1)$ of MRT antigen (stained brucella antigen) was added. The tubes were mixed thoroughly and incubated at $37{ }^{\circ} \mathrm{C}$ for $3 \mathrm{~h}$. The positive results was indicated by the darker cream layer according to (Alton et al., 1988).

\section{3-Enzyme-Linked Immunosorbent Assay (ELISA):}

The test was performed as described by the manufacturer from Synbiotic, France.

\section{4-Isolation and identification of Brucella spp. from the milks amples:}

The cream and sediment obtained after centrifugation (10 minutes at $5000 \mathrm{rpm}$ ) of $50 \mathrm{ml}$ of milk were seeded on plates of Brucella agar medium (Oxoid), suspected colonies were characterized by biochemical tests such as oxidase, catalase, urease, $\mathrm{CO}_{2}$ requirement, $\mathrm{H}_{2} \mathrm{~S}$ production, methyl red, in dole and sensitivity to thion in and basic fuchsin dyes according to (Maymona et al., 2014).

5- Molecular characterization (Detection of Brucella spp. gene) by using polymerase chain reaction (PCR):

Primer set sequences used for Amplification of Brucella spp. was done according to (Baily et al., 1992). Amplification of $223 \mathrm{bpb}$ and confirmed the isolate to be Brucella spp.

DNA amplification of Brucella spp. gene: A $500 \mu \mathrm{l}$ of each milk sample was mixed with $100 \mu \mathrm{l}$ of NET (50mM NaCl-125 mM EDTA-50 mMTris- $\mathrm{mCl}, \mathrm{pH}$ 7.6). After incubation at $80^{\circ} \mathrm{C}$ for 15 minutes, sodium dodecyl sulfate (SDS) and proteinase $\mathrm{K}$ were added in a final concentration of $0.5 \%$ and $200 \mu \mathrm{g} / \mathrm{ml}$, respectively. After incubation at $50^{\circ} \mathrm{C}$ for 3 hours, the cell debris was removed by precipitation with $5 \mathrm{M}$ $\mathrm{NaCl}$ and a hexadecyl trimethyl ammonium bromide$\mathrm{NaCl}$ solution at $65^{\circ} \mathrm{C}$ for 10 minutes (Wilson et al., 1990) After extraction of the DNA (Sambrook et al., 1989), the extracted DNA pellet from each milk sample was resuspended in $25 \mu$ of sterile distilled water and one $\mu \mathrm{g}$ of this DNA suspension was added to the PCR mixture. Reaction mixture of $50 \mu \mathrm{l}$ containing 10x PCR buffer $(500 \mathrm{mM} \mathrm{KCl} ; 100$ mMTrisHCl, pH 9.0; $1 \%$ Triton $\mathrm{x}-1001.5 \mathrm{mMMgCl}$, Promega, USA), 20 mMdNTPs (Boehringer Mannheim, Germany), 2.5 units of Taq DNA polymerase (Promega, USA), $1 \mu \mathrm{g}$ of extracted DNA and 100 pmole of primer. Negative control consisted of sterile water instead of the DNA template was used. The thermal cycler (MJ research, USA) was programmed as first initial denaturation at $94^{\circ} \mathrm{C}$ for one minute followed by 39 cycles consisting of $94^{\circ} \mathrm{C}$ for one minute, $55^{\circ} \mathrm{C}$ for one minute and $72^{\circ} \mathrm{C}$ for one minute and 10 minutes at $74^{\circ} \mathrm{C}$ for final extension (Baily et al., 1992). The amplified product was resolved using $1.5 \%$ agarose gel electrophoresis that stained with ethidium bromide and photographed by photo-documentation system (UVP, USA) and analyzed by Gel-pro 3.1 Analyzer (MEDIA, USA) (Sambrook et al., 1989).

Table1: Oligonucleotide primers for Brucella spp. according to (Baily et al., 1992).

\begin{tabular}{cccc}
\hline Primer Code & Sequence (5' to 3) & Product Size & Species Specificity \\
\hline B4 & TGGCTCGGTTGCCAATATCAA & \multirow{2}{*}{$223 \mathrm{bp}$} & All \\
B5 & CGCGCTTGCCTTTCAGGTCTG & Brucella spp. \\
\hline
\end{tabular}

\section{RESULTS}

Table 2: Incidence of Brucella spp. present in marketable milk samples collected from cow and buffaloes by using MRT, ELISA, direct culture and PCR methods.

\begin{tabular}{|c|c|c|c|c|c|c|c|c|c|}
\hline \multirow{3}{*}{ Milk Samples } & \multirow{3}{*}{$\begin{array}{l}\text { No. of the } \\
\text { examined } \\
\text { samples }\end{array}$} & \multirow{2}{*}{\multicolumn{2}{|c|}{$\frac{\text { MRT }}{\text { Positive samples }}$}} & \multirow{2}{*}{\multicolumn{2}{|c|}{$\begin{array}{c}\text { ELISA } \\
\text { Positive samples }\end{array}$}} & \multirow{2}{*}{\multicolumn{2}{|c|}{$\begin{array}{c}\text { Directculture } \\
\text { Positive samples }\end{array}$}} & \multirow{2}{*}{\multicolumn{2}{|c|}{$\begin{array}{c}\text { PCR } \\
\text { Positive samples }\end{array}$}} \\
\hline & & & & & & & & & \\
\hline & & No. & $\%$ & No. & $\%$ & No. & $\%$ & No. & $\%$ \\
\hline Cow's milk & 70 & 7 & $10 \%$ & 19 & $27.1 \%$ & 3 & $4.3 \%$ & 6 & $8.6 \%$ \\
\hline Buffalo's milk & 100 & 9 & $9 \%$ & 16 & $16 \%$ & 5 & $5 \%$ & 8 & $8 \%$ \\
\hline Total & 170 & 16 & $9.4 \%$ & 35 & $20.6 \%$ & 8 & $4.7 \%$ & 14 & $8.2 \%$ \\
\hline
\end{tabular}




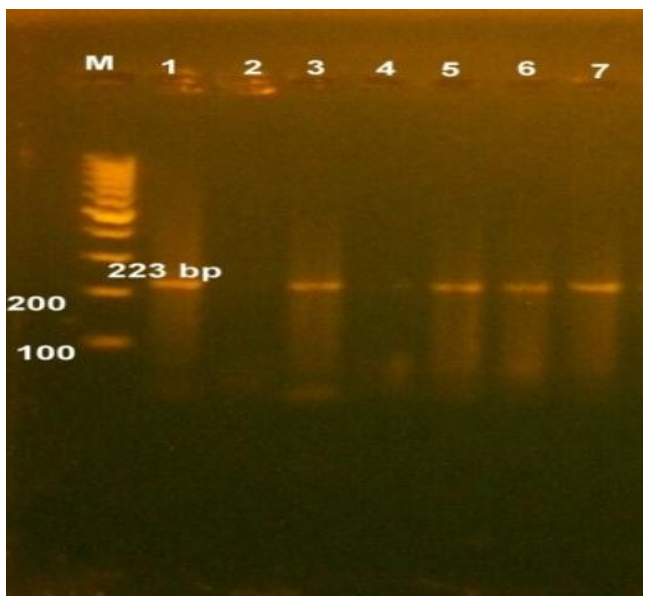

Figure (1): Agarose gel electrophoresis of multiplex PCR for detection of Brucella spp.

Lane M: Molecular weight marker (Gene Ruler 100 bp).

Lanes 1-3: Positive cow's milk samples DNA (223 bp).

Lane 4: Negative cow's milk samples.

\section{DISCUSSION}

Brucellosis is common in rural areas because farmers live in close contact with their animals and often consume fresh unpasteurized dairy products. However, the vending of dairy products may also bring the disease to urban areas (Abd EL -Razik et al., 2007).

The obtained results in Table 2 are not agree with the Egyptian Organization for standardization and Quality Control (E.O.S.Q.C.) (2005) which recorded that milk must be free from the pathogenic bacteria. Higher and lower results for detection of Brucellaein raw milk by using MRT and ELISA were recorded by many researchers [Farag (1998), Hamdy and Amin (2002), Abdalla and Hamid (2012), Ibrahim et al. (2012) and Abo-shama, (2013)]. Serological tests are faster but antigen-antibody interactions can be faulted by non-specific interactions. (Mohsen, 2000).

Higher numbers of the positive milk samples for Brucella spp. was obtained by PCR in comparison to the direct culture applied in the present study. And that may be attributed to the ability of PCR to detect the specific gene of the bacteria regardless living or dead organism (Amin et al., 1995); (Brodie and Sinton, 1975). Microbiological culture depends on organism viability, quality of the sample, contamination of the sample with other microorganisms and time between collection and analysis, while DNA detection by PCR does not depend on these factors.

The 223 bp RNA gene was amplified by PCR indicating 14 milk samples with Brucella spp. (Fig.1)

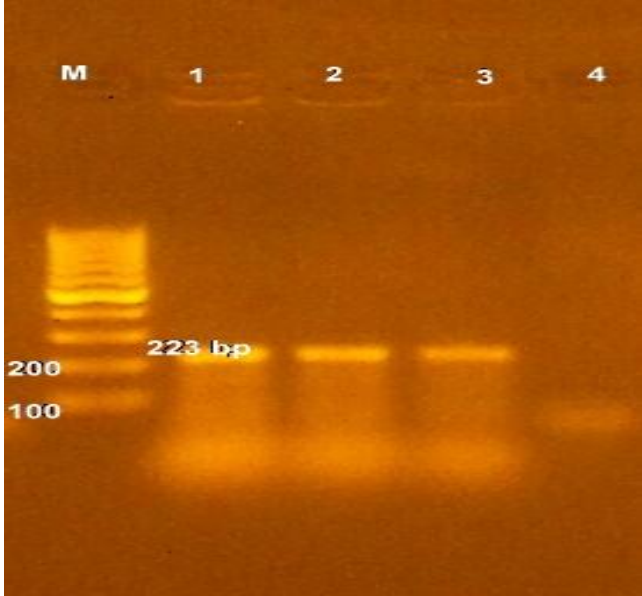

Figure (2): Agarose gel electrophoresis of multiplex PCR for detection of Brucella spp.

Lane M: Molecular weight marker (Gene Ruler 100 bp).

Lanes 1, 3, 5, 6,7: Positive buffalo's milk samples DNA (223 bp).

Lanes 2,4: Negative buffalo's milk samples.

and (Fig.2) which, confirmed to be Brucella spp. strains. This assay offers a very specific, quick and reliable technique. Sequence analysis of $16 \mathrm{~S}$ rRNA gene is extensively used for molecular detection of different bacterial species; 16SrRNA gene sequence among Brucella species is significantly conserved and it has been reported that $16 \mathrm{~S}$ rRNA gene sequencing is a reliable tool for rapid genus level identification of Brucella (Fitch et al., 1990). PCR was done mostly on isolated colonies in order to confirm the routine diagnostic procedure and it was concluded that PCR is a good diagnostic tool to evaluate presence or absence of Brucella species in the grown culture. Finally, Brucella is inactivated by pasteurization or by prolonged boiling for $10 \mathrm{~min}$ (Abbas and Aldeewan, 2009); So, consumption of un-pasteurized milk or milk products prepared under unsuitable conditions exhibit the level of potential risk for public health (Kasimoglu, 2002).

\section{REFERENCES}

Abbas, B.A. and Aldeewan, A.B. (2009): Occurrence and epidemiology of Brucella spp. in raw milk samples at Basrahprov-ince, Iraq. Bulgarian Journal of Veterinary Medicine, 12, No2, 136142.

Abdalla, A. and Hamid, M.E. (2012): Comparison of conventional and non-conventional techniques for the diagnosis of bovine brucellosis in Sudan. Trop. Anim. Health Prod.; 44 (6): 1151-5.

Abd El-Razik, K.A.; Ghazi Y.A. and Salama E.M. (2007): Monitoring of brucella reactor does following milk examination using different techniques. Pak. J. Biol. Sci., 10: 240-244. 
Abo-shama (2013): Detection of Brucella melitensis biovar 3 in cattle's milk from a dairy farm at Sohag Governorate, SCVMJ, XVIII (2): 8797.

Adams, M.R. and Moss, M.O. (1995): Food microbiology. The Royal Society of Chemistry, Cambridge.

Alton, G.G.; Jones, LM.; Angus, RD. and Verger, JM JM. (1988): Techniques for the brucellosis laboratory. Institute National de la Recherche Agronomique, Paris, France, 13(6): 420

Amin, A.S.; Husseinen, H.S.; Radwan, G.S.; Shalaby, M.N.H. and El-Danaf, N. (1995): The polymerase chain reaction assay as a rapid and sensitive test for detection of brucella antigen in field samples. J. Egypt, Vet. Med. Ass., 55(3): 761-787.

Baily, GG.; Krahn, JB.; Drasar, BS. and Stoker, NG. (1992): Detection of Brucella melitensis and Brucella abortus by DNA amplification. J Trop Med Hyg.; 95 (4):271-5.

Bricker, B.J. (2002): PCR as a diagnostic tool for brucellosis. Vet. Microbiol. 90:435-446.

Brodie, J. and Sinton, G. (1975): Fluid and solid media for isolation of Brucella abortus. J. Hyg. (Lond) 74(3): 359-67.

Corbel, M.J. and Brinley-Morgan, W.J. (1984): Genus Brucella Meyer and Shaw 1920, 173, p. 377-388. In N.R. Krieg and J.G. Holt (ed.), Bergey's manual of systematic bacteriology, vol. 1. The Williams and Wilkins Co., Baltimore. Brucella Research Evans. J. Infect. Dis., 23: 354, 1918.

Cordes, D.O. and Carter, M.E. (1979): Persistency of Brucellaabortus infection in six herds of Cattle under brucellosis eradication. New Zealand Vet. J., 27:255-259.

Egyptian Organization for standardization and Quality Control (E.O.S.Q.C.) (2005): For raw milk, No. 1-154.

FAO/WHO (1995): Human brucellosis in Abruzzoprovince. Newsletter, 12 (5): 46- 47.

Farag, Hanaa F. (1998): Screening and Confirmatory methods for detection of Brucellosis in milk of some dairy animals in Behera Province. A thesis of M.V. Sc., Faculty of Veterinary Medicine Alexandria University.

Fitch, T.A.; Bearden, SW.; Sowa, BA. and Marquis, H. (1990): Genetic variation at the omp2 porin locus of the brucellae: species specific markers. Mol Microbiol.; 4:1135-4230.

Hassan, A. and Samaha, M. (2008): "Viability of Brucella melitensis Biovar 3, in Milk and Some Dairy Products. "Egyptian Journal of Medical Microbiology, 17(2): 179.

Hamdy, ME. and Amin, AS. (2002): Detection of Brucella species in the milk of infected cattle, sheep, goats and camels by PCR. Vet J. May;163(3): 299-305.

Hoover, D.L.; Nikolich, M.P.; Izadjoo, M.J. Borschel, R.H. and Bhattacharjee, A.K. (2004):
Development of new Brucella vaccines by molecular methods. In: I.López-Goñi and I. Moriyón, Editors, Brucella: molecular and cellular biology, Horizon Bioscience, Norfolk pp. 369-402.

Hopper, B.R.; Sanborn, M.R. and Bantle, J.A. (1989): Detection of Brucella abortus in mammalian tissue, using biotinylated, whole genomic DNA as a molecular probe. Am. J. Vet. Res. 50 (12): 2064-2068.

Ibrahim, A.K.; Abeer, A.; Abdel All and Amin, A.S. (2012): Long-Term Diagnostic Studies for Detection of Brucella spp. in Milk Samples. Global Veterinaria 8 (1): 54-61.

Kasimoglu, A. (2002): Determination of Brucella spp in raw milk and Turkish white cheese in Kirikkale. Dtsh. Teraratl. Wochenschr. 109: 293-332.

Kazemi, B.; Yousefi Namin, S.A.; Dowlatshahi, M.; Bandepour, M.; Kafilzadeh, F.; Gachkar, L.; Mahmoudinejad, F.; Samarghandi, A. and Mardani, M. (2008): "Detection of Brucella by peripheral blood PCR and comparison with culture and serological methods in suspected cases." Iranian J. Publ. Health., 37 (4): 96102.

Maymona, AM.; Mohamed, TS.; Abdulwahab, YA. and Musa, TM. (2014): Phenotypic characterization of Brucella melitensis isolated from livestock in Abu Dhabi Emirate. Afr J. Microbiol Res.; 8: 3523-8.

Mohsen, A. (2000): "Molecular detection of Brucella in milk using polymerase chain reaction". Czech J. Food Sci., 18 (2000): 95-97.

Moreno, E.; Cloeckaert, A. and Moriyon, I. (2002): Brucella evaluation and taxonomy. Vet. Microbiol 90: 209-227.

Refai, M. (2003): Application of biotechnology in the diagnosis and control of brucellosisin the Near East Region. World J. Microbiol. Biotechnol., 19: 443-449.

Romero C.; Gamazo, C.; Pardo, M. and Lopez-Goňi, I. (1995): Specific detection of Brucella DNA by PCR. J. Clin. Microbiol., 33: 615-617.

Sambrook, J.E.F.; Fritsch, E. and Maniatis, T. (1989): Molecular cloning: A Laboratory Manual, 2 ed. Cold Spring Harbor laboratory press, New York.

Wallach, J.C.; Mignel, S.E.; Baldi, P.C.; Guernera, F.A.; Goldbaum, F.A. and Fossati, C.A. (1994): Urban outbreak of a Brucella melitensis infection in an Argentine family: clinical and diagnostic aspects. FEMS Immunol. Med. Microbiol., 8: 49-56.

Wilson, K.H.; Blitchington, R.B. and Greene, R.C. (1990): Amplification of bacterial16S ribosomal DNA with polymerase chain reaction. J. Clin. Microbial., 9: 1942-1946.

Young, EJ. (1983): Human brucellosis. Rev. Infec. Dis. 5: 821-842. 


\section{الكثف عن البروسيلا في الألبان المباعة فى مدينة الإسكندرية \\ أمانسي فرج زايل ، خالد عبل السميع أبو جازيه ، مجلى ثابت جرجس}

Email: amany.zayed4@yahoo.com Assiut University web-site: www.aun.edu.eg

هدفت هذه الدراسة الى الكثف عن ميكروب البروسيلا في الألبان المباعه فى مدينه الإسكندرية باستخدام طرق مختلفة مثل اختبار

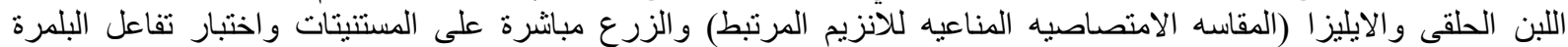

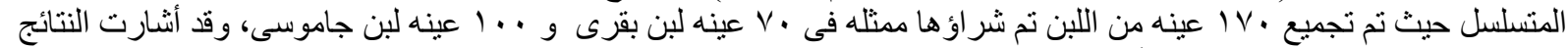

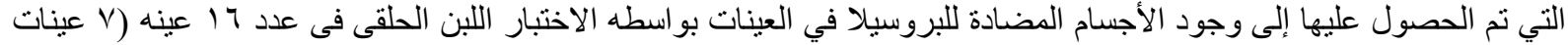

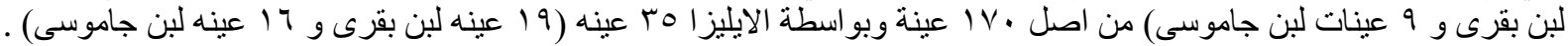

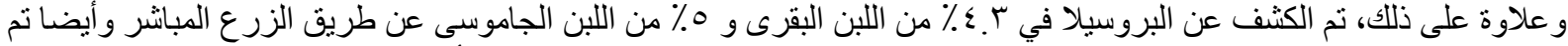

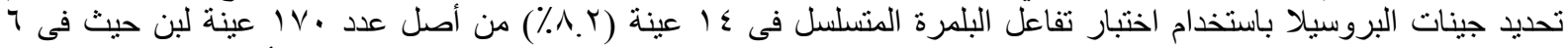

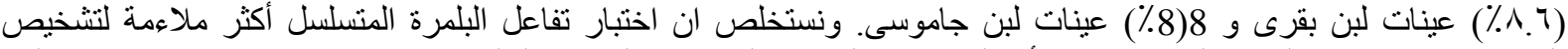

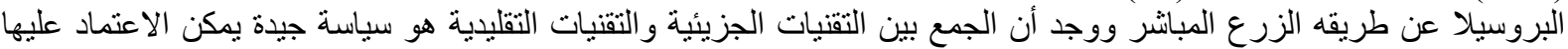
للسيطرة على المرض. وقد حققت نتائج الدر اسه الحاليه تحذير المخاطر الصحة العامة خاصة بسبب عادة شرب اللبن التين الخام الطازج.

الكلمات الداله : البروسيلا ، الالبان المباعه ، اختبار اللبن الحلقى ، الايليز ، اختبار تفاعل البلمرة المتسلسل. 